own than La Follette's. It was because influential Progressives in the State had, in and before 1911, already won control of the Republican party, and they were unwilling to risk losing it either to the Standpatters or to another Progressive faction.

\title{
ONE HUNDRED AND NINETY DAYS IN REBEL PRISONS
}

\author{
By William H. Allen \\ Co. G., 17thi Iowa Vet. Vol. Infantry
}

William H. Allen came with his family from Ohio to settle at Knoxville, Iowa, in the early 1850's. He enlisted April 10, 1862, at the age of 18 in the 17th Iowa Volunteer Infantry, composed of 10 companies and totaling 958 men. The famed 17th Iowa fought at the battles of Corinth, Iuka, and Jackson (Vicksburg Campaign) before it was ordered to Memphis as part of Sherman's Army. In December of 1863, the 17th marched to Huntsville, Alabama, where it spent the winter and spring guarding large supply trains. In April of 1864, the majority of the regiment re-enlisted as "Veteran Volunteers." Of the number of men who had started from Keokuk two years earlier, 352 were left remaining for duty. The 17th Iowa was just about to join the main army at the front, when it was separated from the 1st Brigade and orderd to return to Tilton, Georgia, where it arrived in July, 1864. Here it was assigned to the duty of guarding the railroad between Dalton and Resaca, a distance of fifteen miles.

Private Allen's account of prison life during the Civil War (which was written from memory after a lapse of thirty-four years) begins with that October morning in 1864 when the 17th lowa found itself hopelessly surrounded by a largely superior force of the enemy.

On a bright October morning down at Tilton, Georgia, the 17th Iowa was doing garrison duty. We had been there since about the first of July, 1864, guarding the railroad from Chat- 
tanooga to Atlantic, so as to keep communication with Sherman's army. We were in good spirits as we expected in a few days to be relieved by other troops, so we could go home on veteran furlough, as we had re-enlisted in February and March before and had not received our furlough.

On the morning of October 13, 1864, we were attacked by Hood's army and our pickets driven in and we were forced back by overwhelming numbers, so we had to take shelter in the block house. About eight or half past eight there were orders to cease firing. When I looked out I saw a flag of truce coming towards the block house. Col. Archer said to the boys, "There is a flag of truce! What shall we do, fight or surrender?" The boys, all of one accord, shouted, "Fight!" Major Archie went out and met the white flag of truce and there he received a demand from Lt. General Alex. P. Stewart, commanding rebel forces, to surrender. Col. Archer's reply was, "If you want me and my men you will have to take them by force, for we will never surrender until we are compelled to." And I wish to state here that our little band only numbered about three hundred men, while the 16th Rebel army corps were all around us, and here we fought until three oclock in the afternoon, when we were compelled to raise the white flag. During all this time the Rebels had two batteries of artillery playing on us, while we had nothing but our muskets.

When we surrendered my first thought was to destroy my gun, which I did by breaking it off at the breech and bending the barrel. The next thought was to hide my money, and I jerked off my shoe and sock, put my money into my sock, pulled them both on again and marched out west of the block house, where we were corraled by the enemy. While here the Johnnies commenced taking our personal effects, such as hats, shoes and blankets, until General Stewart stopped them. We did not stay here but a short time until they started us on the march up the railroad in the direction of Dalton. They marched us within a short distance of Dalton, where they camped us for the night, and nothing to eat the next morning. There were two or three boys missing, who had gotten away during the night, Wm. H. McBride, of Có. G, and Johnnie Cannon, a drummer boy. 
We were marched up through Dalton, thence from Dalton we were taken south over Dug Gap into the valley. Then they took us down the valley and when we passed the mouth of Snake Creek Gap our men and the Rebels were fighting in the gap not more than half a mile away, but not such good luck for us as to see them break through and recapture us. They marched us on till night and camped again with nothing to eat. After we had been in camp for some little time, they marched a regiment of Negroes up and camped them a short distance behind us. They had been captured at Dalton, their white officer not allowing them to fire a gun. All the whites at the fort were paroled.

The next morning we resumed our journey with the colored boys behind us. They marched us all day and went into camp again with the colored regiment a little ways behind us. The next morning when we got up the colored regiment was gone and that was the last we ever saw or heard of them. We were marched all day and camped again at night, this being the fourth day. We were issued a small piece of corn bread and a little piece of beef. Here at this camp Capt. Hicks and Lt. Swearngin got a guard from Col. Weatherspoon, the Rebel officer in charge of us, to go over the hill to a house to get supper. After they got over the hill they downed the guard, took him prisoner and double quicked over the hill for three or four miles, then turned him loose, but kept his gun. They got to Coosa River and in swimming the river, Capt. Hicks drowned, a noble man and as brave a soldier as ever wore the blue. Swearngin had to take to the hills alone and made our lines the next moming at Rome, Georgia.

Now we came back and resumed our march toward the Blue Mountain railroad. We passed through a number of small towns - Summerville, Galesville [Alabama], Center, Jacksonville, Anniston, Jenifer. At Galesville, eight Michigan boys joined us from the 6th Cavalry along with one deserter from an Illinois regiment.

The Rebels finally got transportation for us and the next place we landed was at Selma, where they put us into a small stockade until the next morning, but we did not get to sleep much during the night for the machine shops were close by and they were running day and night. 
They marched us out and down to the levy at the steamboat landing on the Alabama River. There was a boat waiting for us so we went aboard and we steamed down the river and landed at Cohaba [Cahawba]. We were ordered on shore and marched up into town. The news got spread around that we were going to be searched and that put the boys to hiding their money. I had at the time something over $\$ 300$ in greenbacks and a small silver watch that I had kept concealed. I had two $\$ 100$ bills and I put one in each boot. The back of my boots were double and open at the top. I put the bills on the end of a stick and shoved them down to the heel. I still had two $\$ 50$ bills to hide. I put one in the back of a likeness case, the other-I bought a loaf of bread and paid one dollar for it, took my knife, cut a hole in the bread and put a fifty in and fixed the bread to look as natural as I could. Then I took off my dress coat and cut a hole in the lining, put my watch into the padding and fastened it there and sewed up the cut. Now I was ready to be searched.

We were marched up in front of the officer in command of the prisoners and there he had his men search us. When it came my turn, I stepped out in front. The Rebel asked me if I had any money, I told him yes, I had a little, some change in script which I had left in my packet to give them to keep them from searching me too close. I handed him two or three dollars. He took it and counted it, then he looked at me and said, "Is that all the money you have?" I said, "Yes, Sir, if you think I have any more, search me, I am at your mercy." He then commenced going through my clothes and pockets. He took the likeness case out of my pocket, in which was the $\$ 50$ bill, and opened it and said, "Who are these?" I said it is my father and mother. "Well, you can keep them," he said, and handed it back to me. Then he commenced searching again and at one time he had his hand on my watch, but did not discover it.

After they were through searching us they marched us into what was called Cohaba prison, an old warehouse on the banks of the Alabama River. The walls were of brick, only one story high. It was quite large, with no floor but the mother earth. On the north side was a fence or stockade where we could look out during the day. The ground here 
was about one-hundred feet across. In this open space we did our cooking, that is, when we had anything to cook. The guards were kept on this stockade during the day, at night they were closed in our warehouse. The first night in prison Comrade Finley Butler and I slept together, and to our surprise when we woke up next morning, found that the raiders had visited us during the night. Butler woke up first, gave me a shake and said, "Allen, get up, the d--d raiders have got all of my money, and my coat and hat!" I raised up on my elbow and said, "No, they are not gone." He said to me, "You had better get up and see what has been taken of yours." I commenced looking, and to my surprise, my watch worth $\$ 30$ and likeness containing a $\$ 50$ bill were gone. Poor Butler was left without a cent of money, no coat or hat and winter coming on. His money was all sewed up in his coat in two or three different places, $\$ 60$ in all. I will explain here what the raiders are. That was a name we had for theiving soldiers who were in the army more for money than love of country. Most of these bounty jumpers were from the large cities and they banded themselves together to rob and steal. I will speak of the raiders again when I get to Lawton and Andersonville. That day Comrade Butler and myself were feeling pretty blue, and we were wandering through the prison to see if we could get any trace of his coat or hat, when we saw several boys standing looking at something. We stepped up to them and saw that they were looking at my father's and mother's likeness. I said to the one that had it, "Where did you get that?" He said he picked it up right there. "That was stolen from me last night," I said. He said if it is yours, you are welcome to it. I took it and at the same time said, "I will see what is inside." I knocked the likeness from the case, but no money was there.

Well, things moved along for about three days, then the 17th Iowa was ordered to get ready to move. They were going to take us to our lines for exchange. We marched out of Cohaba and it was a sorrowful day for the 17th Iowa, for we went from good shelter and protection from the winter's blast into the open pens, with nothing but the heavens over us.

We boarded a steamboat, cut loose and started up the river. We passed Selma and the next place we landed was Mont- 
gomery, Alabama. We were marched off the boat and up the hill east, then turned north over into a deep hollow, or ravine, where they corraled us for a few hours. Then they marched us over to the depot, where we were ordered on some stock cars, and the next place we landed was at Columbus, Georgia, where we were corraled until next morning. During the night Capt. Skelton, of Co. D, Capt. Deal, of Co. C, and Lt. Hudson, of Co. G, made their escape and worked their way to our lines. That morning we were loaded on the cars again and moved on our way through Ft. Valley and on through Macon, thence to Millen Junction, where they moved us out a few miles on the Augusta road. They stopped the train and ordered us off, formed us in lines and started west. After about one mile, we came to a stockade or prison. The big doors swung open and we marched inside one of those hells on earth-Lawton prison!

We were ordered into the northeast corner, a flat piece of ground. The rain was pouring down in torrents, water almost shoe deep on the ground, and we were told this would be our quarters. That was when you could begin to hear cuss words from the little band of 17 th Iowa boys. It took brave hearts to stand on battlefields and see the dead and dying and not flinch, but it took even braver hearts to enter one of those prison hells without breaking down in grief. This prison had about thirty acres of ground very near square, with a small stream of water running from north to south, which gave us a good water supply. The enclosure was made of logs set on end, about twelve feet high, with sentry boxes on top of logs about every one-hundred feet. The dead line was three foot stakes driven into the ground with strips of boards nailed on them, and this was about twelve feet inside of the logs. The guards had orders to shoot any Yank crossing the dead line.

We stood around in the water and rain, not even a place to sit down without sitting in the water. The other prisoners came flocking from the west side of the prison to see the fresh fish, as they called us, and to get the news, as they only heard of the progress of the war by the arrival of new prisoners.

I started out to take in the sights around the prison. I went south toward the southeast comer, where they told me 
the hospital was, but I did not go far until my heart failed me and I turned back with the tears streaming down my cheeks to see those poor, sick men lying there in the water, not able to sit up and torrents of rain falling and nothing but the heavens to cover them. As I went down to the hospital, on an old blanket in the water were three boys, two of them were cold in death and the third was sitting between the two with no clothing on but an old shirt and a pair of drawers. He was shaking and chilling in the cold November rain and moaning the most pitiful sounds that ever came from the lips of man. I said to him, "Can I do anything for you?" He answered with a weak and trembling voice, "No, I want to die, these are my two brothers, and I want to go with them." I turned away and left him for I could do him no good.

The next moring the three brothers lay side by side, they had answered to the last roll call. That morning there were sixty-two dead carried to the gate and laid side by side, waiting for the wagons that hauled our rations to take a load of them out. They would load about twenty dead bodies in one wagon. We stayed in the northeast corner of the prison that night. The next morning they moved us to the southwest corner, where we had a better camping ground. The day was bright and sunny which made us feel in better spirits than the evening before. We settled down to every day life in prison, each drawing our little scanty ration and cooking and eating it and then waiting another.twenty-four hours for another bite.

The Presidential election was coming on and there was a lot of talk about Father Abe and Little Mack. So the captain commanding the prison, Cameron, I think was his name, agreed to let us hold an election and vote for President. Cameron thought we would vote for Mack because our Government had left us in prison so long without exchanging, and he would send the vote North in our lines and let people know we had gone back on Father Abe. So when election day came he furnished us a box to vote in, and we had judges chosen and the polls closed at two o'clock. The ballots were pine chips with the name "Lincoln" or "McClelland" written on them. In the evening when the ballots were counted, Lincoln had about seven thousand five.hundred, while McClelland 
had about two hundred and fifty. When Capt. Cameron came in to get the returns, he looked at them and commenced cussing the Yanks until the prison air was blue with his vile epitaphs. As he started out of the prison the boys yelled at him, "Are you going to send that vote North?" Well, the vote never came North.

A few days later they commenced on the sick exchange. They went through the prison and selected some two hundred men. There were twenty-five nurses to go with them, and the men who had the most money were the ones who got to go. There were several of the boys who died after their names were taken down and their comrades fixed themselves up and crippled to the gate and answered to the dead men's names and walked out.

During our stay here the raiders and Dick Allen, one of the regulators from Andersonville, had a fight in the north end of prison. I heard someone yell, "The raiders are killing Dick Allen!" There was a rush made for the raiders and they scattered and Dick came out all right.

Word came of another exchange, and they commenced moving the prisoners as fast as they could by the train load, but we knew that it was exchange to another prison. On the night of the 21st day of November, about midnight, we were marched out of Lawton prison with the rain pouring down in torrents. They marched us to the railroad and put us into stock cars with excrement from stock, shoe-deep. Then they came along and dumped our rations for two days in the car of filth, and we had to eat or do without. We were soon on the move back to Millen. This time we took the Savannah road. The next evening we were at Savannah where we lay on the cars until late in the evening.

We traveled all night and early in the morning we stopped at Black Shear, Pierce Co., Georgia, where we were ordered off the cars. We formed in line and were marched out in the heavy timber and swamps, about two or three miles from town. Black Shear is the county seat of Pierce county. It is almost impossible for me to describe the town, for there was nothing to be seen but two or three old wooden structures there in the timber. We would have done very well if they had given us plenty to eat, for we had lots of wood and pine 
boughs to make a shelter. There were about five thousand of us there. We were corraled close to a swamp, and there was a heavy chain guard all around. At night the guard was doubled and during the day there was a gap allowed in the line at the southwest corner of camp so we could go down to the swamp, accompanied by guards, to get water. While here one of our boys was shot and killed by a little Johnny at the gap where we went out for water. He happened to turn a little too soon and stepped one foot on the beat of the guard and the Rebel gave him no warning, but shot him through the bowels. He lived a few hours and breathed his last in the most horrible pain.

We stayed here about ten days or two weeks. Then there were orders to get ready-we were going to be paroled this time sure. They even called for one thousand men to go out on the first train load for Savannah. Everybody tried to get out with the first train load. When they had the number they wanted counted out, they stopped them just outside our lines and had them sign a parole, but instead of going to our lines, they went to Florence, South Carolina, to prison again. After this train load went through, Gen. Foster made a raid from the gulf and destroyed the railroad so that they had to find some other place for the rest of us.

In a day or two we got orders to move. We had some little time before we were to leave and several of the boys dug holes in the ground and got into them and had the others cover them up with dirt and pine boughs. The Rebels moved us outside, then they stopped us and set fire to the camp. Some of the boys in the holes were not covered sufficiently, so they had to break out through the blaze. One Indian boy was badly burned.

As we marched to the station I saw three Georgia girls coming to market with their mule. The mule looked old enough to have been in Noah's Ark. The bridle was made of rope, the collar was made of corn shucks, the tugs were ropes, the hames were made out of the root of a tree, the cart wheels had been sawed off a gum tree, the frame of the bed was put together with wooden pins and the shafts on either side of the mule were larger than our wagon tongues. Two of these Georgia belles were in the cart with the produce, the 
third was astride the mule with her feet resting on the shafts and a stock of sugar cane in one hand and the bridle rope in the other, guiding the mule. I had a good laugh over this.

We were marched up to the station, ordered on the cars and started south. This time we landed at Thomasville, Georgia, in the end of the gulf board. Here we were marched southwest into the timber again, which was a Godsend for us, as it gave us plenty of wood to burn. Here they put about one hundred darkies to digging a trench around us so wide and deep we could not cross it. Then they put their garrison on the other side of the trench. Our rations here were a little better than they had been at the former places. After we had been here about ten days, they brought in an Indian boy who had tried to escape. He hobbled in on crutches, for they had run him down with blood hounds and they had clawed him so he could scarcely move. His arms and legs were chewed so you could see the bones. They kept us here about two weeks, and on the 19th day of December they moved us again. This time we had to go afoot. We found our destination was Albany, sixty-three miles from Thomasville. This was a great hardship on us, for a good many of the boys were almost naked, and I think one-fifth of them bare-footed. The weather was getting cold. Some mornings the ground would be frozen a little when we would start out, and you could track the boys by the blood from their feet along the road. The 4th Georgia militia guided us through and they were terribly abusive, especially one Capt. Grant, whom the boys couldn't help but recall as being very brutal. While we were on this tramp to Albany my recollections carry me back to the day when this Capt. Grant was in charge of the rear guard and one of the boys who was sick, gave out and fell in the road, not being able to walk any longer. I dropped back close to the rear to see what would be done with this sick man. Capt. Grant came to him, ordering him to get up and move on. The sick man cried, "Captain, I can't go! I have only a few minutes to live, and for God's sake let me lie here and die in peace." But no, he ordered the guards to put their bayonets to him. The poor fellow made an effort to get up, but failed, and he crawled on his hands and knees about fifty yards and fell over dead. They picked him up and threw him to one 
side of the road and left him there. This same Capt. Grant drew his sword on W. E. Dixon, of my company, and made a motion to strike him, but Bill wasn't the scary kind. He said to him, "Strike me, I am at your mercy, you infernal coward! Why don't you go to the front where there are live Yankees and not stay back here abusing prisoners?"

About all the amusement we had on this trip came each morning when they would move us out and turn the blood hounds loose in our camp to smell out the Yanks who had buried themselves during the night. The dogs would go all over the ground smelling and sniffing. Whenever they began to dig and bark you might bet there was a Yank there. The boys were dug out and turned in with the rest of us. Then we would laugh at them and they would say a few cuss words about the hounds.

On the evening of the 23rd day of December we came to Albany on the Flint River. Coming from Ft. Valley down through Andersonville, we stayed here all night on the banks of the river. Next morning they took one train load up to Andersonville and I was in the first train. About three o'clock on the 24th day of December, 1864, we were marched into the prison.

When we landed at the station we got the first sight of that Demon Wirz. Well do I remember my first sight of him. He came walking up to the prisoners where we had unloaded from the cars. He said, "Get them damn Yanks in de road by four time so I count dem." He meant in four ranks. We were formed in four ranks in fours and Wirz came along counting us. He came to one file where there were five. He stopped, jerked out his revolvers and said (I will not use the language he-did), "The next file I find mit five, I makes four!" Well, after some time he got one hundred of us counted off. We were the 7th hundred in the prison. We lay to the south of the street running east from the south gate. Our hundred extended from the street to the south end of the stockade.

- We had a sergeant for each hundred to draw rations each day when the Rebels hauled them in. We divided into squads of twenty-five and had a man to draw rations from the head sergeant of a hundred. Our rations consisted of about twothirds of a pint of corn meal, not sifted or bolted, and about 
two spoonsful of peas. These peas were inhabited by a little black bug, sometimes as many as three in a pea, but they all went into the kettle, as they helped to season. Those that came out of the peas and raised to the top of the water were taken off. When we ate we could feel the bugs crushing in our teeth. Some days this would be our rations for twentyfour hours. We would draw a small amount of beef, then again we would draw a little molasses, and this is what we had to live on. Those who had money could purchase from the guards after night. You could get one bushel of corn meal for $\$ 1$ in greenbacks or $\$ 30$ in Confederate money. Sweet potatoes ran about the same price.

We had what we called Market Street. You could go down there and get corn bread or mush if you had any money. Mush was 5 cents a dish with molasses on it, to suit your own taste. If you would step up to a lunch counter here in God's country, and see a man standing behind the counter as dirty as these men were, I don't think your stomach would relish any of the eatables. They were as black as pine tar could make them, and so were all the rest of us. Just think of being for months without soap and nothing to burn but pitch pine wood. Our wood supply was so scarce that we had to shave it up into small splinters and use it to cook with only. While we were cooking we would hover over the fire to keep warm, and that is why we would get so black. And even if we had plenty of wood to heat some water for washing, we could not stand it hot enough on our flesh to cut the tar.

Every morning about nine o'clock the Rebel sergeant would come to call the roll. We would hear him call out, "All you Yanks get in two strings thar while I count you all." Our hundred would sometimes have a man out for water, then some one of the boys would play it on the sergeant to make the count come out all right. One of the boys would slip down behind and fall in at the foot and be counted again. About once a week you could see Wirz riding in on his old gray mare, and ten or twelve Rebel guards with him to protect him from the prisoners, as he was afraid to come inside alone. He never had a good word for a Yankee. When he came inside he was cursing and using the most vile language that a human tongue could utter. 
The winter had come and here we were, with no shelter, no fuel to build fires to keep us warm. Our clothing was worn out and dropping off piece by piece, so that about one out of five had nothing but shirt and drawers to protect him from the cold, chilly rains and freezing nights. When one of the prisoners would die who had a coat or pair of pants on, the breath would hardly be out of him before some poor fellow would come along, take his clothes off and put them on. If we asked him why he took the dead man's clothes, he would say, "They are of no use to him and they may be the means of saving my life." Ninety-nine out of a hundred that died in prison were stripped of clothing. Go to the gate in the morning after the dead were carried there and look at them and see those skeletons, nothing but skin and bone, not many months before they were the pride of our army. I have seen two of the boys fighting over a comrade who was about to breathe his last, to see which would get his clothes. My readers, you may think that I am exaggerating when I write this, but it is all true, and my pen fails to describe what a man could see there.

The raiders were not very bad during the winter, only a small amount of petty thieving. There was only one man killed by the raiders during our stay there. One night about ten o'clock we heard the cry of murder, on the north side. We rushed over and found a comrade lying there on the ground with two stabs from a knife in the breast. He was dying, but he was able to talk a little. He said, "He stabbed me, then took my money and ran. I only had one dollar in greenbacks and two dollars in Confederate." The poor fellow only lived a few hours.

One cold, stormy night someone in the prison stole a strip off the dead line. The next morning it was discovered and reported to Wirz. He sent word inside the prison that we could not have any more rations until the Yank who stole the dead line came out and gave himself up. We were at a loss to know what to do, for we knew that the demon would not give us a morsel to eat until the man gave himself up. We did not know the man, so our only show to get anything to eat was to hire someone to go out and acknowledge taking the little strip of board from the dead line, and the only thing we had to 
hire him with was the promise of extra rations. We hired a small drummer boy who was almost naked and so starved he was nothing but skin and bone. The boy went to the gate and told the sergeant that he wanted to be taken to headquarters, for he was the one who stole the piece of wood. There was a guard sent with him to Wirz when he reported. He told Wirz he stole the wood from the dead line to build a fire to keep himself from freezing and he did not want the boys in the prison to starve on his account. Wirz looked the boy over and his heart melted for once. He said to the guard, "Take this boy to the cook house and give him a chunk of corn bread and turn him inside." When the boy came back inside without punishment, we felt good and cheered him; and that afternoon we got our rations and the drummer boy got his thirty-six rations we agreed to give him. This was the only kind act by Wirz during his reign at Andersonville, or at least it is to only one I ever heard of.

Along in February I took the chills and fever. It was then that I began to think the Confederacy would outlive me, for I knew I could not last long. My money was all gone and I had no way to get anything to break the chills. I was walking through the prison and found the back of a gutta-percha comb. It was about two inches long and something less than a half-inch wide. The thought struck we that I could make a finger ring out of it. So I took my knife and went to work cutting a slot hole in it. Then I got a stick and made it round and pointed, held the point to the fire until it got warm, shoved the stick in the slot, made it round and dressed and polished it. Then I walked around the prison, looking at each guard in the sentry boxes until I saw one who I thought was all right. I told him I had a nice ring I would give him for a double handful of dogwood bark, that he could bring the bark when he came on post that night and I would be there. He came on at ten o'clock, and I made the exchange with him. I made some tea next morning and commenced drinking it, and soon the chills stopped. I kept the balance of the bark until after I passed the last Rebel at Block River, in the rear of Vicksburg, then I threw it in the river.

While in those prisons we got no news from the outside world except from newly captured prisoners who were turned 
in. The Rebels would not allow us to have any papers. While there I wrote one letter to my parents that went through to Knoxville, Iowa. We were only allowed to write on one side of a sheet of letter paper. In that letter I wrote more lies than I had ever written before or since. My object in writing as I did was to get my letter through to let my folks know that I was alive and well, as I knew the Rebels would read it. Part of my letter read: "Dear Parents: This leaves me well. We are having a fine time here and plenty to eat. Not much sickness ..." and so on in this strain, until I used up what space I had to write.

New Year's day, 1865, came during our stay at "Hotel De Andersonville." Captain Wirz made a dinner, and among his invited guests was General Winder, Commander-in-Chief of Southern prisons. When the dinner was ready and they were seated, Winder fell dead at the table. The rumor was that before the breath left him he said, "Captain Wirz, cut the Yankees' rations down, they are getting too much to eat." If Wirz had obeyed orders, we would have been leaner than we were, if such a thing could be.

Along in March we commenced getting word of exchange, through the Rebel guards, and that was the one thing most talked about. In fact, we spoke of nothing else. Finally, "Old Demon" Wirz came in on "Old Gray" and told us we were going to be exchanged and that he would commence sending us out in a few days. Then, if ever there was a lot of poor, wretched, starving creatures that cheered, it was the boys in Andersonville. In a few days they commenced moving us, and those who had any money left got to go first. I, myself, and others in my company gave $\$ 5$ each to get out.

On the 25th of March, 1865, we marched out of Hades, went to the station and bade farewell to Wirz, Andersonville and Sumter Co., Georgia. We came north until we struck Fort Valley, where we took the same old trail back. We landed at Montgomery the next evening after leaving Andersonville. We were put on a steamer and taken down the river to Selma, where we landed. In the morning we were marched off of the boat and taken through the town west to the depot and there corralled. We could sense there was something unusual going on about the town, and when we got to the depot where we 
could see to the west, we knew the Yankees were coming to pay a visit to Selma.

They did not tarry long with us here. The passenger train was about ready to go, loaded with citizens leaving town to get away from the Yankees. The captain in charge of us ordered the train unloaded. When it was empty, he ordered us on board in passenger cars. This was the only time we had seen inside of a coach during our stay with them. As we left the town we passed along by their breastworks [hastily built walls for defense] and the next place we landed was at Demopolis, Alabama, on the Tombigbee River. Here we stayed a few hours corralled on the levy, until a boat came up the river to meet us. Then we were ordered aboard and they pulled down the river a few miles, then landed. We were ordered off and put on the cars again. We had not gone far until the engine stalled on a hill. They ordered us off the cars and then wanted us to push the train up the hill. We were on the road to God's country and, of course, we would do all we could to get along. We got up the hill and landed at Meridian, Mississippi, that night. Here they marched us down and put us in a stockade for the night. Next morning we were taken out and put on cars again and the next place we landed was at Jackson, Mississippi, on the banks of the Pearl River. We were marched through to the western part of the town where we camped for the night.

The next morning we started on foot for Black River. That morning we passed over one of our battle grounds where we had fought on the 14th day of May, 1863. Many of the graves of the 17th Iowa boys who fell in that battle were plain to be seen. Next we came to the bloody field of Champion Hills, one of the hardest fought battles, for the time it lasted, during the war.

Our traveling on foot was very slow, for there were not many. who could walk without something to support them. We finally came to Black River, where we could look across and see our men on the rise of the hill, cooking coffee and getting ready for us. We were detained a short time, then we were turned loose. As we marched onto the Pontoon bridge, a cavalryman jerked from his inside clothes a little cavalry flag and held it above his head and waved it, and 
that brought forth cheer after cheer as we crossed the bridge. When we came up to the boys who were making coffee, we thought we would get all we could eat, but again we were on short rations. They formed us in a line and gave each of us about half a tin cup of coffee and a small cracker. That was all they would let us have.

It was a week or ten days before they would let us have full rations. We were kept in parole camp, four miles in the rear of Vicksburg. While there we received the news of the assassination of Abraham Lincoln. The Rebel Major in charge of us got the news before we did, and he wasn't long getting started for the other side of the Black River. The Provost marshal from Vicksburg sent word to him that he had better go, for he would not be responsible for anything the prisoners did. So he flew for the other side of the river and left our men to parole us. This was on the 20th day of April, 1865.

I wish to say in conclusion, that what I have written is from recollection, except a few dates that $I$ have in a passbook I carry with me.

Wimliam H. Allen

Co. G, 17th Iowa Vet. Vol. Inft.

\section{MUSEUM NOTES}

A letter written by Abraham Lincoln to Iowa's Major General Samuel R. Curtis, dated from the Executive Mansion, November 6, 1862, was found in the Curtis Papers at the State Historical Department by Gerald Duffas, a Drake University graduate student in American History. As far as is known there is no previous record of this letter's existence. The brief note contains the following: "I feel it my duty to you as a friend to tell you that the Sec. of War and General-in-Chief inform me that charges have been preferred against you, something about speculating in cotton, so I understand, which can not be overlooked-I am sorry to write on so unpleasant a subject. The matter will be held until I have time to hear from you. Yours truly. A. Lincoln." 
Copyright of Annals of Iowa is the property of State of Iowa, by \& through the State Historical Society of Iowa and its content may not be copied or emailed to multiple sites or posted to a listserv without the copyright holder's express written permission. However, users may print, download, or email articles for individual use. 